introduction, terminology hinting at experiential foundations (or givens) abounds: 'one cohesive vision that is grounded on a concern and commitment to experience,' 'Dewey's underlying but very personal faith in experience ... is, for me, the ultimate glue of Dewey's vision,' and 'a pre-reflective, qualitatively felt present situation ... [is] the ultimate source of guidance in moral life' (pp. 12-13). Apropos of this concern, Colin Koopman has imparted some advice to present-day pragmatists, generally, which could be directed at Pappas, specifically, 'To avoid this foundationalism ... contemporary pragmatists who are eager to revive the concept of experience must be on guard to not treat experience as a kind of ultimate given-ness against which we might be able to measure our truth claims' (Colin Koopman, 2007).

Overall, though, Pappas's book is a significant contribution to the sparse literature on Dewey's ethics, which is surely to inspire debates among Dewey scholars and provide a valuable introduction to new readers of Dewey's ethical writings.

\title{
References
}

Dewey, J. (2000) Dewey on Democracy. Ithaca and London: Cornell University Press.

Koopman, C. (2007) Language as a form of experience: Reconciling classical pragmatism and neopragmatism. Transactions of the Charles S. Peirce Society 43(4): 694-727, 697.

Shane Ralston

Pennsylvania State University-Hazleton and World Campus,

Hazleton PA, USA

\section{Messy morality, the challenge of politics}

\author{
C.A.J. Coady \\ Clarendon Press, Oxford, 2008, 160 pp., £14.99/\$29.95, ISBN: 0199212082
}

Contemporary Political Theory (2010) 9, 253-256. doi:10.1057/cpt.2009.21

Tony Coady's book is another in the Oxford Uehiro series in Practical Ethics and it expands Uehiro Lectures given by its author in 2005. There is perhaps no 
more pressing practical matter than the one this book addresses - namely how to make normative theory work in the all too real and extremely 'messy' world. In particular, Coady is concerned to address and rebut the challenge of those cynics about politics who, having appropriated the title of 'realists', think that morality is overrated and overused.

Under the description of 'moralism', and in his first two chapters, Coady brings together a series of alleged failings of an overreaching morality, some of which he thinks well observed, others less so. In the third chapter, he addresses the proper role of ideals. In the fourth chapter, he asks whether politics has to be amoral and does so through an extended discussion of the influential account of 'dirty hands' given by Michael Walzer, a view Coady himself believes to be 'confusing'. In the final chapter, he gives short shrift to the idea that it might be permissible for politicians systematically and regularly to lie.

Those who take morality, and moral philosophy, seriously must commend Coady for reminding us that these should know, and keep to, their place. Not everything can be seen in moral terms; nor should some moral matters be given an unwarranted importance besides others. In his view, however, morality does have a place in politics. Hence, his dissatisfaction with the 'dirty hands' view that politics is necessarily and seriously amoral or the view that politicians must lie. He himself acknowledges that he is mainly dealing with the 'heavy end of the spectrum' of 'immoralities'. It would have been interesting then to hear more about the light end and indeed about whether what politicians must do on a daily basis - such as logroll, compromise, patch together coalitions of diverse views, employ rhetoric and spin - counts as immoral. The world of politics can be and very often is tawdry, vulgar and confused. The clear- and pure-minded ideas of the moral philosopher may be hard to apply in such a world. But, they need to be, and how that application is to be managed is itself a task the moral philosopher needs to take up.

Coady's list of the forms that moralism can take is nicely constructed. I would add another and qualify an existing one. His choice of Dicken's admirably drawn character, Saul Pecksniff, is a good one. But, Pecksniff is more than just morally smug or arrogant; he is a hypocrite quick to see virtues in his own character which has none, and not to see them in others deserving of approbation. His moralism wreaks havoc in the lives of those he falsely judges, and yet he is not - as are others of Dickens' characters, likes Bill Sykes or James Carker - an evil person. The moralist can be immoral yet strangely pitiable.

Coady identifies as one form of moralism, 'absolutism', which he defines as an inflexibility or rigorism in the application of moral categories. This, he thinks, leads to an unbalanced concentration on some moral value and indeed to a demonisation of those on the other side of the moral fence. There is 
a slightly distinct failing, that of unbendingness or of a rigid sense of rectitude that can be principled and pluralist, need not be unbalanced in its judgment of moral matters and need not demonise those who disagree, but which is nevertheless politically dangerous if directly translated into action. It is not quite the fanaticism against which Isaiah Berlin cautioned in his lifelong suspicion of those who pursue 'big ideas'. Nevertheless, a failure to make moral compromises is, it seems to me, worthy of the description 'moralism'. Indeed, one of the biggest problems facing the liberal moral and political philosopher is to understand how a citizen may combine an unwavering sense of the rightness of his own views with an acknowledgement that he must live together with those who have an equally clear view that their contrary moral outlook is right.

Coady's principal focus is what is done by political actors but he has in mind, and criticises, those who are the major actors - governments and their leaders. Equally, his worries are about, as he says, 'those political performances that tend to wreak the most havoc' in our world, namely political violence and war. Against the background of the continuing ill effects of the invasion of Iraq, his concerns are understandable. But, we are all, or should be political actors, and that of course includes moral philosophers. Tony Coady has a distinguished history not just as a philosopher, but as public intellectual in his own Australia, having spoken out in public forums on many matters of controversy. It would be interesting to hear more about how those who cannot wreak the most havoc can and should act in the 'messy' political realm with both philosophical and moral integrity.

There is a final point to be made about ideals. Coady's discussion of their role and in particular of the criticism that they are unrealisable is intelligent and nuanced. He is surely right to insist that they can play a valuable function in directing us to make a better world. But, it would have been good to see him address the view, recently articulated by Amartya Sen, that politically ideal ('transcendental') states of affairs, however cogently described, are of no help whatsoever in making comparative judgements of those suboptimal states we must choose between. For Sen, it would indeed be wonderful if we could create an ideally just society, but we are unlikely to be able to do so; we must, however, combat injustice and to do that we must set to one side the ideal which gives us no guidance in how to conduct this fight.

Those who know Tony Coady's writing will find its customary qualities on display - pellucid prose, philosophical intelligence, wit, and a fierce and impatient disdain for those who abuse the privileges of power or the requirements of rational argument. More and more is now being written about the demands of normative philosophy in a non-ideal world. Coady is unsympathetic to the Rawlsian distinction between ideal and non-ideal theories. But, this elegant essay is a worthy addition to the literature on the latter. 


\title{
Reference
}

Amartya Sen, (2006) What do we want from a theory of justice. The Journal of Philosophy CIII (5): $215-38$.

David Archard

Department of Philosophy, University of Lancaster,

Lancaster, UK

\section{The philosophy of Simone de Beauvoir: Ambiguity, conversion, resistance}

\author{
Penelope Deutscher \\ Cambridge University Press, Cambridge and New York, 2008, cloth, 199pp., \\ $£ 45, \$ 81$, ISBN: 978-0521885201
}

Contemporary Political Theory (2010) 9, 256-258. doi:10.1057/cpt.2009.22

In this important addition to the Cambridge Ideas in Context series, edited by Quentin Skinner and James Tully, Penelope Deutscher does indeed place the work of Simone de Beauvoir within its intellectual context. She provides an original and erudite treatment of Beauvoir's engagement with, and transformative 'conversions' of, the ideas of a wide range of her contemporaries (French and otherwise) as well as many prior thinkers. She also offers a reading of the many creative, and often incompatible, conversions that key concepts within Beauvoir's own body of work undergo, both within and among her texts.

Through reading Beauvoir as a thinker whose concepts not only shift but also often productively undermine, or 'autoresist,' themselves, Deutscher also speaks to contemporary debates about how, more generally, to make sense of incoherence and instability within a thinker's work. Rather than attempting to fix the most precise meaning of a concept, or to search for greater coherence in a body of work, Deutscher advocates mining fluid, unstable, or even contradictory, aspects. For these need not express intellectual failings on the part of a thinker (be it Beauvoir or another). Rather they are expressive of what Deutscher calls 'the multivalent ambiguity' of life, and they assist us in grasping 'our state of existing in various divided modes that cannot be reconciled' (p. 7).

For example, Beauvoir is often accused of logical inconsistency in The Second Sex since she asserts, on the one hand, that to be human is always to be free and, on the other, that women are not free. Instead, Deutscher argues,

256 (C) 2010 Macmillan Publishers Ltd. 1470-8914 Contemporary Political Theory Vol. 9, 2, 251-261 